DOI 10. $18307 / 2020.0508$

(C) 2020 by Journal of Lake Sciences

\title{
前言
}

1921 年,竺可桢先生在《科学》杂志发表了《杭州西湖生成之原因》一文, 距今已一百年, 这可能是我国 现代湖泊科学的最早文献. 1940 年中国地理研究所在重庆北碚成立,抗战胜利后搬迁至南京. 1953 年, 中国 科学院地理研究所在南京正式成立. 1958 年研究所设立了湖泊组 (组长施成熙), 揭开了中国现代湖泊科学 研究的序幕. 1987 年, 研究所更名为中国科学院南京地理与湖泊研究所 (以下简称地湖所). 时光萑䓁, 地湖 所湖泊科学研究从早期的认知湖泊 (科学考察、野外台站监测) 到围绕我国不同时期湖泊资源、环境、生态需 求而开展了湖泊沉积学、物理湖泊学、湖泊生物资源利用、富营养化控制、淡水生态学、水环境修复等基础和 应用基础研究; 与此同时, 以农业地理和区域地理为特色的国情地理研究逐步与湖泊流域研究相融合, 近年 来发展了流域地理学这一新的学科方向.

30 多年来, 地湖所围绕湖泊科学和流域地理学两大特色学科方向, 紧扣国家需求, 取得了一大批具有开 拓性和独创性的成果. 开创中国国情分析研究, 率先提出建立节约型国民经济体系; 编著《中国人民共和国 国家农业地图集》等重要专题地图,推动了我国区域地理学的发展; 系统开展长江中下游资源、生态、环境、 城市化与区域发展研究, 建立了流域集成研究方法体系; 开展我国湖泊综合调查与科学考察, 建成了全国性 的湖泊数据库, 创建我国湖泊流域科学的理论体系; 通过湖泊沉积重建了区域气候和环境, 发展了生态系统 服务长期演变研究方法; 开拓了我国湖泊湿地资源高效利用的模式, 提出了大水面以 “三网” 养殖技术为核 心的湖泊水体农业模式. 地湖所已成为国内外有重要影响的地理与湖泊科学研究基地.

为庆祝地湖所成立 80 周年, 《湖泊科学》邀请国内长期从事湖泊和流域科学研究的多名学者, 就不同分 支领域的进展进行了系统回顾, 内容涉及浅水湖泊湖沼学与太湖富营养化控制 (秦伯强)、湖沼学的内涵及 我国湖沼学发展的挑战与思考 (刘正文等)、湖泊环境与工程学 (江和龙等)、湖泊水文水资源学 (张奇等)、 湖泊古生态学 (羊向东等)、湖泊水情遥感 (宋春桥等) 等多个方向. 此外, 我们还组织了有关知名专家就当 前湖泊科学研究的热点话题和焦点问题发表他们的学术观点, 如太湖 40 年来的物理水环境变化 (张运林 等)、沉积物环保疏浚决策 (范成新等)、1960s 以来白洋淀水文/环境/生态演变 (易雨君等)、中华鲟保护的 困境与反思 (危起伟、黄真理等)、蓝藻水华的认知与预测 (朱广伟、朱伟、史小丽等)、富营养化湖/库天一空一 地立体监控系统 (段洪涛等) 等.

我们希望本期专刊的出版, 能为我国湖泊科学相关方向的发展作阶段性的梳理, 同时为未来相关研究 趋势提供一些深人的思考. 随着地表系统科学的不断发展, 以及 “山水林田湖草” 系统保护和修复战略的全 面推进, 地湖所作为我国唯一以湖泊科学研究为特色的国家研究机构, 将竭力为我国饮用水安全保障、淡水 生物多样性保护、水生态系统服务提升和可持续流域管理等未来生态文明建设核心任务提供技术支撑, 努 力成为全球湖泊变化、淡水生态系统、流域水环境保护研究的主力军. 2020 年的长江流域特大洪水, 也给我 国湖泊和流域科学研究提出了新的挑战, 如三峡水库等的优化调度与长江中下游洪水, 特大洪水后江一湖关 系及两湖调蓄功能的新变化, 流域层面大中型水库的综合效应, 未来洪一旱交替的机制、预警及减灾思考, 水 资源保护利用与水体富营养化的关系等等, 将是未来我国湖泊和流域科学必须要深人思考和研究的科学 问题. 


\section{Preface for the Special Issue on Celebrating the 80th Anniversary of Nanjing Institute of Geography and Limnology, Chinese Academy of Sciences}

One hundred years ago, Prof. Chu Kochen published “On the origins of the West Lake (Hangzhou)" in the journal Kexue (Science) in 1921. In 1940, the Chinese Institute of Geography was founded in Beibei (Chongqing), then moved to Nanjing after the victory of Anti-Japanese War. In 1953, the Institute of Geography (Academia Sinica) was officially established in Nanjing, and soon after the Lake Group was set up (directed by Shi Chengxi) in 1958, which announced modern lake research in China. In 1987, the institute changed its name to Nanjing Institute of Geography and Limnology, Chinese Academy of Sciences ( NIGLAS). Since then, NIGLAS have witnessed lake research progresses in China, from early activities such as lake survey to the comprehensive studies of lake sedimentology, physics, biological resource, eutrophication control, freshwater ecology, aquatic environment restoration and so on to meet the needs of national resource utilization, environment protection and ecological restoration in different times. Meanwhile, NIGLAS have developed novel watershed geography after integrating rural geography, regional studies and lake research.

In recent 30 years, NIGLAS have achieved a number of pioneering outputs in distinctive fields of limnology and watershed geography, and turned out to be an influential base on the geographical and limnological research both at home and abroad. It pioneered analytical study of national conditions and proposed a saving-style national economy strategy; edited important thematic maps such as “Agricultural Atlas of China” which essentially promoted the progress of regional geography; systematically studied natural resources, ecology, environment and urbanization in the lower Yangtze River area, thus developed integrated watershed study methodology; conducted comprehensive lake survey and established national lake information system and based on that created the systematic lake sciences in China; built a high efficiency utilization model for lake and wetland resources and proposed new aquaculture models for large surface waters. The institute has become an important research base for watershed geography and lake science with both domestic and international reputation.

To celebrate the 80th anniversary of NIGLAS, Journal of Lake Sciences invited some distinguished scholars who have long been engaged in relevant fields to conduct a systematic review of the progress in different sub-fields, such as shallow lake limnology and Lake Taihu eutrophication, the connotation of limnology and the challenge/reflection on the limnology development in China, lake environment and engineering, lake hydrology and water resources, lake paleo-ecology, remote sensing of water regimes. In addition, we also organized well-known experts to publish their scientific and academic views on current hot topics and focal lakes, i.e. 40-year physical changes in Lake Taihu, environmental protection for dredging decisions, evolution of Lake Baiyangdian since 1960s, Chinese sturgeon protection reflection, cyanobacteria blooms mitigation and Satellite-Aerial-Ground 3-D monitoring system for eutrophic lake/reservoirs.

We hope that the publication of this special issue will provide a systematic review of lake science development in China, andbring certain in-depth thinking for the future. With the continuous developing of earth surface system science and advancing of national integrative "Mountain-water-forest-field-lake-grass" system protection and restoration strategy in China, NIGLAS, as the only national research institute featuring lake science, aims to provide scientific and technological support for the key ecological civilization construction tasks, such as national drinking water safety, freshwater biodiversity protection, aquatic ecosystem services improving, and sustainable watershed management. NIGLAS will strive to become the main force in research on global lake change, freshwater ecosystem, and watershed environmental protection. The catastrophic floods in the Yangtze River Basin in 2020 brings new challenges to the lake science and catchment studies in China, such as the optimized regulation of the Three Gorges Reservoir, reflection on floods mitigation and river-lake relationship, regulative function change of watershed-scale lakes and reservoirs, future flood-drought alternates mechanism and disaster mitigation, interrelations of water resources protection, utilization and eutrophication.

Prof. Zhang Ganlin, Director of NIGLAS September, 2020 